Marquette University

e-Publications@Marquette

$1-1-2016$

\title{
The Integrative Justice Model: Fair, Ethical, and Innovative Marketing to the Poor
}

Gene R. Laczniak

Marquette University, eugene.laczniak@marquette.edu

Nicholas J. C. Santos

Marquette University, nicholas.santos@marquette.edu

Published version. "The Integrative Justice Model: Fair, Ethical, and Innovative Marketing to the Poor," in Ethical Innovation in Business and the Economy. Eds. Georges Enderle and Patrick E. Murphy. Cheltenham, UK: Edward Elgar Publishing, 2016: 261-280. Publisher link. (c) 2016 Edward Elgar. Used with permission. 


\section{The integrative justice model: fair, ethical, and innovative marketing to the poor}

\section{Gene R. Laczniak and Nicholas J.C. Santos}

\subsection{INTRODUCTION}

Writing in the Journal of Public Policy \& Marketing (JPP\&M), Santos and Laczniak (2009b) introduced the 'integrative justice model' (IJM) for marketing to poor and disadvantaged consumers. This normative-ethical model, inspired by writings in moral philosophy, marketing theory, corporate social responsibility (CSR) frameworks as well as religious traditions, postulates five inter-related components that appear essential for treating poor consumers in a fair and just manner. Basically, the IJM is a normative model outlining what is owed to vulnerable, impoverished consumers when they enter into marketplace transactions with more powerful sellers.

The prescriptive components of the IJM, described in detail in that article, are: (1) authentic engagement without exploitative intent; (2) cocreation of value with customers; (3) investment in future consump- tion; (4) genuine interest representation; and (5) focus on long-term profit management (Figure 13.1). These principles are meant to capture the essence of ethical obligations owed by the seller to buyers due to the latter's relative lack of power. The IJM principles are further intended to describe the ethical dimensions necessary to nurture just exchanges with vulnerable consumers. The idealized outcomes of applying the IJM when marketing to disadvantaged consumers would be: longer-term relationships, customer empowerment, sustainable business practices and, most centrally, the creation of a fairer marketplace at the micro-, meso-, and macro-levels. 


\section{VALUE INPUTS}

- Authentic engagement with consumers, particularly impoverished ones, with nonexploitive intent

- Co-creation of value with customers, especially those who are impoverished or disadvantaged

- Investment in future consumption without endangering the environment

- Interest representation of all stakeholders, particularly impoverished customers

- Focus on long-term profit management rather than short-term profit maximization

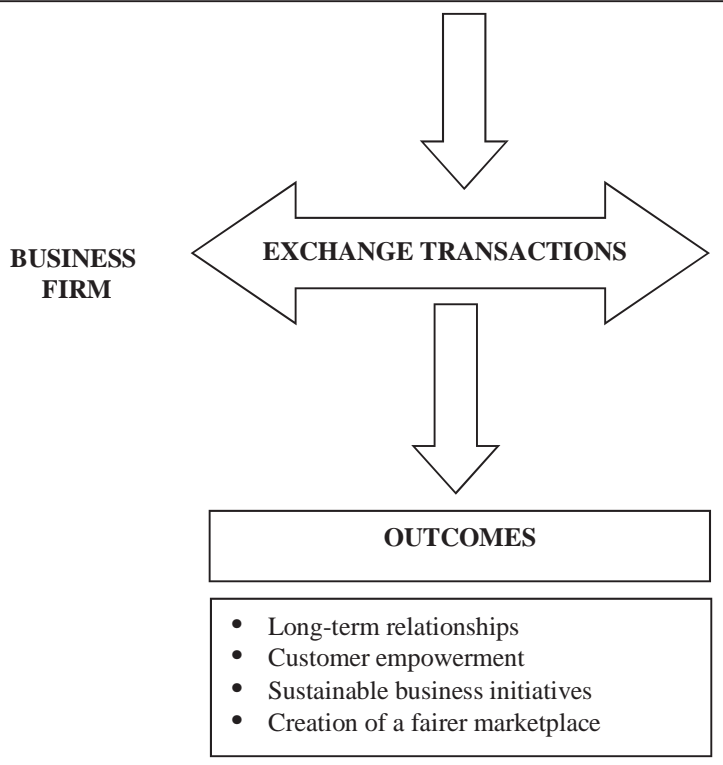

Source: Santos and Laczniak (2009b).

\section{Figure 13.1 An integrative justice model for impoverished markets}

We propose that the IJM is a model of ethical innovation in marketing to the poor in at least two respects. First, in contrast to descriptiveexplicative models, the IJM is a normative-ethical model that is comprised of five key components that ought to be present when marketing to the poor. As such, unlike most of the mainstream marketing models that do not articulate their implied ethical or unethical values, the IJM makes the ethical dimension explicit. Second, the IJM is also different in substantive ethical terms: it is about justice (not exploitation), honesty (not deception), and sustainability (not short-term operations). 
Our purpose in this chapter is to introduce the IJM for those who may not be familiar with it and to describe how the IJM has been systematically developed, via programmatic scholarship and analysis, to clarify its usefulness and begin to certify its validity. Given the heightened business interest in low-income markets in both the developing and developed world, and considering the historical exploitation of the populations in these markets, the urgency of promoting models such as the IJM, with their explicit emphasis on ethics and fairness, cannot be overemphasized.

\subsection{DERIVATION OF THE MODEL}

The theoretical justification of any normative-ethical model can be painstaking and elaborate. No matter what the approach, the heart of the matter lies in the logic and persuasiveness of evidence and argumentation. With the IJM, we tried to follow the developmental guidelines of John Bishop (2000) for normative theory formulation in the articulation of the key IJM principles. He proposes that every normative theory needs to address seven issues: (1) recommended values, (2) the grounds for accepting those values, (3) a decision principle that business people who accept the theory can use, (4) who the normative theory applies to (that is, the agents), (5) whose interests need to be considered (in other words, the decision principle's scope), (6) in what contexts it applies, and (7) what legal and regulatory structures it assumes. Some of the essentials of that deliberation are included in the original JPP\&M article, but much of the detailed commentary was presented in previous (in other words, pre2009) conference papers where aspects of the IJM inspiration were addressed piecemeal but in more detail than academic journal publication normally allows. For example, in a paper presented at a London Business School conference on CSR (Santos and Laczniak, 2006), we conducted a strengths-weaknesses-opportunities-threats (SWOT) analysis of the market construction model (MCM) proposed by Harvard researchers Rangan and McCaffrey (2004) (Table 13.1).

The MCM was presented as a model to aid developmental projects in emerging markets and was designed to be more customer empowering than usual approaches. The MCM was focused on representing the oftenunrepresented interests of the poor client and giving greater voice to such clients by bringing their interests to the table of planning and decision-making. Our analysis revealed certain positive elements of the MCM but also certain dimensions that needed to be included. This exercise led to us proposing a modified MCM (Table 13.2) that served as a foundation for further development and derivation of the IJM. 


\section{Table 13.1 A SWOT analysis of the market construction model}

\begin{tabular}{|c|c|}
\hline \multicolumn{2}{|l|}{ Internal } \\
\hline Strengths & Weaknesses \\
\hline $\begin{array}{l}\text { Engages the poor with } \\
\text { non-exploitive intent } \\
\text { Implements Levitt's (1983) global } \\
\text { product idea with 'genuine' customer } \\
\text { orientation } \\
\text { Consistent with Vargo and Lusch's } \\
\text { (2004) product co-creation idea } \\
\text { Provides possible 'first mover' } \\
\text { advantage for early adopters } \\
\text { Shapes better brand equity by } \\
\text { building trust with skeptical } \\
\text { customers } \\
\text { Product co-creation as well as } \\
\text { co-production would lead to greater } \\
\text { acceptance of the corporation by the } \\
\text { local community }\end{array}$ & $\begin{array}{l}\text { Does not consider possible corruption of } \\
\text { local business partners } \\
\text { There are presently no proven metrics for } \\
\text { measuring success using the model } \\
\text { Cedes too much control to customers } \\
\text { (marketing mania) } \\
\text { May not meet company's } \\
\text { return-on-investment targets or other } \\
\text { short run financial measures }\end{array}$ \\
\hline \multicolumn{2}{|l|}{ External } \\
\hline Opportunities & Threats \\
\hline $\begin{array}{l}\text { Consistent with twenty-first-century } \\
\text { sustainable economic development } \\
\text { movement and the triple- } \\
\text { bottom-line approach } \\
\text { Congruent with 'socially } \\
\text { responsible' investing } \\
\text { Similar to bottom of the pyramid } \\
\text { business frameworks such as the } \\
\text { BOP Protocol } \\
\text { Positive PR opportunity based on } \\
\text { authentic engagement }\end{array}$ & $\begin{array}{l}\text { Political risk of markets is considerable } \\
\text { and not accounted for (nationalization, } \\
\text { war, extortion) } \\
\text { Inherent pressure for ever greater local } \\
\text { autonomy (loss of control) } \\
\text { Vulnerable markets are increasingly } \\
\text { scrutinized and mistakes will become } \\
\text { public (negative PR) }\end{array}$ \\
\hline
\end{tabular}

Source: Santos and Laczniak (2006).

Subsequently, in some post-2009 publications, we also attempted to illustrate how the IJM was deeply rooted and connected to other values/theory frameworks that have been widely discussed in the business literature. In other words, rather than merely sourcing the IJM to a singular moral philosophy or business framework, we tried to drill deep showing how the IJM connected with assorted ethical argumentation in the broad literature. First, for example, in Santos and Laczniak (2009a), we illustrate how the elements of the IJM are sympathetic to the longstanding traditions of Catholic social thought and their spirit of 'preferential option for the poor' as well as the 'protection of the most 
Table 13.2 Modified market construction model

Model Framework

Functional processes

Interest representation of all stakeholders, especially

consumers

Mandated advocacy for the poor

Co-creation of value with all stakeholders, especially consumers

Aim

Long-term profit management

Change lives (macro)

Outcomes

Reconciliation of values and interests

Customer empowerment

Long-term relationships

Sustainable business initiatives

Business role

Including unrepresented customer interests

Facilitating value creation

Investing in future consumption

Vision

Laying the foundation for prototype markets that

empower the poor while creating 'win-win' situations

for buyers and sellers

Source: Santos and Laczniak (2006).

vulnerable in society' - two essential and long-endorsed principles for the achievement of social justice.

Second, in Laczniak and Santos (2011), we show the normative elements of the IJM are connected to the service-dominant (S-D) logic conception of exchange (Vargo and Lusch, 2004, 2006, 2008), an ascendant 'theory of marketing' meant to descriptively explain the service focus of all market transactions. Therein, the IJM is argued to be highly consistent with the foundational elements of S-D logic, especially the dimensions that speak to the analysis and importance of balanced exchange; that is, a form of distributive justice.

In terms of derivation of the model, the IJM does not blend different theories or types of justice such as procedural or legal justice. Instead, it integrates the notion of 'fairness' or 'equity' in marketing transactions as developed from an examination of different perspectives. These perspectives were: (1) Catholic social teaching; (2) Habermas's discourse theory; (3) Kant's categorical imperative; (4) Rawls's difference principle; (5) Ross's theory of duties; (6) Sen's capability approach; (7) virtue ethics; (8) classical utilitarianism; (9) S-D logic of marketing; (10) socially responsible investing; (11) stakeholder theory; (12) sustainability; and 
(13) the triple bottom line. The five key principles of the IJM emerged from an examination of these different thought streams.

As an illustration, the theories that provide a normative foundation for the first IJM principle, which is an authentic engagement without intending to exploit the disadvantaged consumer, are Catholic social teaching (CST), Immanuel Kant's categorical imperative (second formulation), Ross's theory of duties (beneficence), S-D logic, and virtue ethics (see Table 13.3 for the theoretical support of each IJM principle). For instance, CST emphasizes the inherent and inviolable dignity of the human person. The second formulation of Kant's categorical imperative decrees never to treat people as merely means to an end. One of Ross's 'prima facie' duties is beneficence, which suggests rendering aid to those in need whenever reasonable. S-D logic places a considerable focus on the centrality of the customer as an active participant in the exchange process. And, virtue ethics emphasizes the role that values play in shaping behavior. All of these frameworks are suggestive of treating customers, particularly impoverished and vulnerable ones, with fairness and without exploitation (Santos and Laczniak, 2012). Likewise, an important theory that provides the normative foundation for the third IJM principle, namely an investment in future consumption, is Amartya Sen's capability approach (Sen, 1999, 2009; Enderle, 2013). Sen’s approach views those living in poverty not merely in terms of a lack of income but rather as capability deprivation that is the result of a lack of entitlements and is characterized by a lack of freedom, whereby the poor are unable to make choices to achieve what they value being and doing.

\subsection{THE IJM AND THE 'BASIC PERSPECTIVES FRAMEWORK' (LACZNIAK AND MURPHY, 2006)}

Some thoughts seem necessary about the connections of the IJM with explicit ethical imperatives that are designed for application to the poor, and normative marketing models in general. The frequency and commonality of normative ethical models of marketing depends upon exactly how one characterizes them (Nill and Schibrowsky, 2007). For instance, one can distinguish between the abundant articles about marketing practice that offer glib ethical adages such as 'it is good not only to satisfy but to delight your customers' or 'treat your suppliers with respect because it's the right thing to do' and, other more comprehensive formulations that are based on an explication of moral theory. The more common, idiosyncratic articles in the marketing ethics literature assert a particular ethical approach based on a sort of moral intuitionism - that is, this 
Table 13.3 Theoretical foundations of the IJM elements

\begin{tabular}{|c|c|}
\hline Proposition & Theory \\
\hline $\begin{array}{l}\text { Authentic engagement with } \\
\text { consumers, particularly } \\
\text { impoverished ones, with } \\
\text { non-exploitative intent }\end{array}$ & $\begin{array}{l}\text { Catholic social teaching (common good, } \\
\text { human dignity, solidarity) } \\
\text { Kant's categorical imperative (1st and 2nd } \\
\text { formulation) } \\
\text { Ross's theory of duties } \\
\text { S-D logic of marketing } \\
\text { Virtue ethics }\end{array}$ \\
\hline $\begin{array}{l}\text { Co-creation of value with } \\
\text { customers, especially those } \\
\text { who are impoverished or } \\
\text { disadvantaged }\end{array}$ & $\begin{array}{l}\text { Catholic social teaching (human dignity, } \\
\text { subsidiarity) } \\
\text { Habermas's discourse theory } \\
\text { Kant's categorical imperative (3rd } \\
\text { formulation) } \\
\text { S-D logic of marketing }\end{array}$ \\
\hline $\begin{array}{l}\text { Investment in future } \\
\text { consumption without } \\
\text { endangering the environment }\end{array}$ & $\begin{array}{l}\text { Catholic social teaching (common good, } \\
\text { human dignity) } \\
\text { Classical utilitarianism } \\
\text { Sen's capability approach } \\
\text { S-D logic of marketing } \\
\text { Sustainability perspective }\end{array}$ \\
\hline $\begin{array}{l}\text { Interest representation of all } \\
\text { stakeholders, particularly } \\
\text { impoverished customers }\end{array}$ & $\begin{array}{l}\text { Catholic social teaching (common good, } \\
\text { subsidiarity) } \\
\text { Classical utilitarianism } \\
\text { Habermas’s discourse theory } \\
\text { Kant’s categorical imperative (2nd } \\
\text { formulation) } \\
\text { Rawls’s difference principle } \\
\text { S-D logic of marketing } \\
\text { Stakeholder theory }\end{array}$ \\
\hline $\begin{array}{l}\text { Focus on long-term profit } \\
\text { management rather than } \\
\text { short-term profit maximization }\end{array}$ & $\begin{array}{l}\text { Catholic social teaching (common good) } \\
\text { Classical utilitarianism } \\
\text { S-D logic of marketing } \\
\text { Socially responsible investing } \\
\text { Triple bottom line }\end{array}$ \\
\hline
\end{tabular}

Source: Laczniak and Santos (2011).

seems like the proper action. The latter, less common, comprehensive, ethical models in marketing derive their ethical propositions with reference to an explicit logic chain rooted in moral philosophy. Dunfee et al. (1999), in postulating their own normative model of marketing ethics based on 'social contract theory', reviewed the marketing ethics literature and found only four comprehensive, normative theories of marketing 
ethics - Laczniak (1983), Williams and Murphy (1990), Reidenbach and Robin (1990) and Smith (1995) - in addition to their own. To briefly illustrate the deeper development involved in comprehensive normative models, Williams and Murphy (1990) ground their observations about marketing ethics based on a detailed examination of 'virtue ethics'; Smith (1995) similarly utilizes a theory of inherent 'consumer sovereignty' to anchor his observations about ethical marketing conduct. In 2006, Laczniak and Murphy offered an encompassing model of normative marketing ethics that, in the ideal, would subsume all those approaches that had come before due to its multi-theory grounding. It is with this latter model of general, normative marketing ethics that the IJM is specifically compared.

Laczniak and Murphy (2006) (L\&M) construct a comprehensive normative approach to marketing ethics based on eight essential basic perspectives (BPs) (Figure 13.2). Each BP is linked to aspects of moral theory or to normative managerial frameworks. The BPs are meant to be viewed as dynamic, interactive, and connected in order to create a broadbased aspirational ideal for ethical behavior in marketing. The BPs have a micro-dimension in that they can be seen as providing ethical norms for marketing firms. But they are macro in that they should be universally advocated for all marketing organizations. This is because they are grounded in an understanding of the role that marketing firms play in society along with an explicit recognition of the social contract that exists between business and society. In addition, at its core, the L\&M approach also pervasively recognizes the fundamental dignity of all persons.

The IJM in focus in this chapter is highly consistent with L\&M's broader normative theory of marketing ethics. Understanding that close connection provides the reader with a perspective about the derivation and robustness of the IJM and how it fits into the larger marketing ethics literature. Both L\&M and the IJM are derived based on the theory development protocol of Bishop (2000). The IJM also operates on similar, albeit more targeted level as the L\&M perspective. Specifically, the IJM is grounded in a macro-understanding of what constitutes a just market for impoverished consumers (see Santos and Laczniak, 2009a, 2009b) and, from such vantage points, ethical prescriptions for all firms that market to the poor consumers are drawn. The consistency of the IJM with L\&M adds to its concurrent and face validity. Below the specific connections between the elements of the IJM and dimensions of the L\&M approach are briefly laid out.

The 'authentic engagement ... with non-exploitative intent', the initial element of the IJM, can be seen as an extension of L\&M's first BP that 'ethical marketing puts people first'. As L\&M (2006) write, 'ethically 


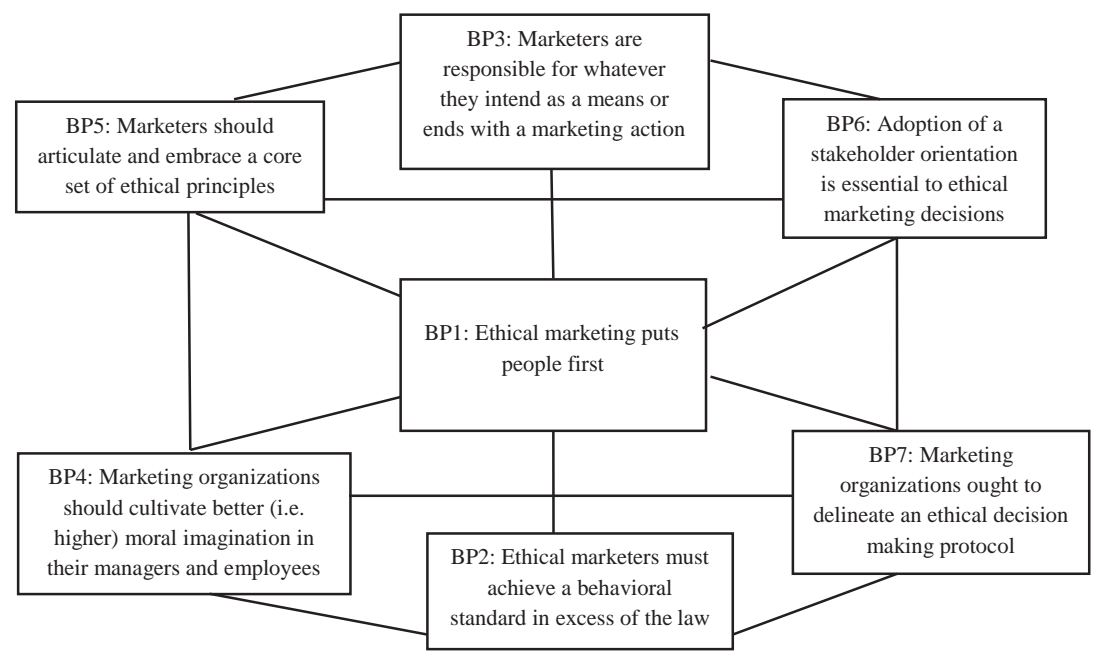

Source: Laczniak and Murphy (2006).

Figure 13.2 A summary of the essential basic perspectives (BPs) for evaluating and improving marketing ethics

concerned marketers should seek to fully comprehend their societal influence and to ensure their marketing operations create a perceived and real benefit' (p. 157). It is also a direct reflection of the sentiments of BP5 where L\&M (2006) articulate that 'marketers who aspire to operate on a higher ethical plane should embrace a core set of ethical principles' (p. 164) including 'the principle of protecting vulnerable market segments' of which the poor are clearly a primary constituent. For example, the American Marketing Association (2008) in its Statement of Ethics reminds its members (academics and practitioners) that they have a special commitment to vulnerable market segments.

'Co-creation of value with customers', the second element of the IJM, can be viewed as embedded in BP3 of the L\&M (2006) framework that suggests that 'marketers are responsible for their intent as well as the means and ends of their marketing actions' (p. 161). Surely one of the easiest ways to generate creative (and ethical) symbiosis - and avoid negative outcomes - is to partner with impoverished customers from the beginning. For example, Amanz' abantu Services, a South African provider of water and sanitation services, involves consumers from the beginning of the innovation process itself (Sprague, 2007; Krämer and Belz, 2008, p. 227). A direct inquiry process conducted during the incubation phase enabled customers to select the design of the sanitation structure. 
Additionally, rural community-based village groups called project steering committees were set up to enable the villagers to play an active role in the project's design and implementation, thereby leading to greater ownership. Such an open innovation paradigm grants consumers 'the role of a "prosumer", integrating him/her actively and deeply in one or - ideally - all stages of the innovation process (invention, incubation, market introduction and diffusion)' (Krämer and Belz, 2008, p. 218).

'Investment in future consumption without endangering the environment' element three of the IJM approach is also reflective of BP5 of the general L\&M (2006) approach. In particular, this BP advocating the adoption of a core set of ethical principle includes 'distributive justice' whereby '[t]here is an obligation on the part of all marketing organizations to assess the fairness of marketplace consequences flowing from their collective marketing practices' (p. 166). An example of an organization following this dictum in the context of the IJM is the SEKEM Group, an Egyptian conglomerate attempting to expand organic farming in the desert northeast of Cairo (Hamm, 2008, p. 53; see also Chapter 10 in this volume). When done right, the 'organic approach' is not only healthier for consumers but can be conducted with less water, without pesticides, and hence it can flourish in harsher terrain. In order to maintain the SEKEM network of 800 independent farmers cultivating 50,000 acres, the company has invested, through its corporate foundation, in a school, medical center, and various social support programs for the villages that have sprung up around the desolate area.

'Interest representation of all stakeholders, particularly impoverished ones' is the fourth element of the IJM. It is in close consonance with L\&M (2006) BP6 stating that, 'The adoption of a stakeholder orientation is essential to the advancement and maintenance of ethical decisionmaking in all marketing organizations' (p. 167). Such attention to the unique needs of impoverished consumers was shown when Grameen Family of Enterprises entered into a partnership with Danone Foods of France to develop and distribute affordable 'single-serving' yogurt portions that were also nutritionally enhanced (Hamm, 2008, p. 51). This particular combination of attributes would not have been required in the developed markets that Danone typically served.

The fifth element of the IJM calls for 'focus on long-term profit management rather than short-term profit maximization'. This evokes BP4 of L\&M (2006), which calls for cultivating managers with moral imagination 'who are such moral exemplars that they will always try to do what is morally right in their marketing decisions' (p. 164). In other words, the ethical organization, when engaging impoverished market segments, desires to train managers capable of creating strategies that 
will generate future sustainability. An excellent example of this sentiment would be the Belgian organization, Apopo (Hamm, 2008, p. 52). Established as a purely altruistic endeavor, the firm creatively trained giant African pouch rats to sniff out landmines in Tanzania so that these killing fields might be safely cleared. When donations flagged, the company contracted with consultants from Saïd Business School, Oxford, UK, to help expand its service applications to Middle Eastern markets and to suggest training the rodents to detect disease in refugee camps and elsewhere. In this manner, Apopo's investment in product development expertise enhanced its likelihood of staying the course in its market of origin.

\subsection{EXTENSION AND DISCUSSION OF THE IJM MODEL}

The process of normative ethics formulation (premise $\rightarrow$ situation description $\rightarrow$ rule articulation $\rightarrow$ supporting rationale) causes many (useful) debates to arise. For example, our nomenclature 'integrative justice model' prompted readers to ask if various theories of justice have been 'blended together' in order to create 'rules' for justly marketing to the poor. Our response is that multiple dimensions of justice have not been mixed but rather that the term 'integrative' refers to the idea that our five deduced ethical principles work in harmony - that is, with integration to create the conditions for fairer exchange with impoverished segments. Of course, this does not necessarily exclude the discussion of other categories of justice - procedural justice, compensatory justice, restorative justice, and so on - with respect to the IJM approach. In fact, below we discuss the essential role of institutions in providing transformational justice (TJ). Therein, we assert that conscientious institutions provide the means to guarantee the power to make sure that impoverished buyers have at least the minimum conditions for honest exchange (McMahon, 1999, 2004). Similarly, we regularly discuss social justice as a possible criterion for the ongoing analysis of current market workings (Laczniak and Santos, 2011).

To the purpose of more fully justifying our model in the academic literature - and despite the generally positive reception from 'blind' academic reviewers - we strove to respond to sundry constructively critical comments about the IJM. In Laczniak and Santos (2011), we detailed (see Table 13.3) the various (non-L\&M) ethical frameworks that had also given inspiration to our five ethical principles. And, we noted that our model for 'responsibly marketing to the poor' had previously 
been compared and contrasted with other published normative approaches for engaging bottom-of-the-pyramid consumers (Santos and Laczniak, 2006). Concerning other constructive criticisms: first, to those who said the model was idealistically aspirational but 'not of much practical use to managers', we examined numerous case studies from global settings, published in the secondary literature, where MNCs had been praised for particular aspects of aiding poor and destitute market segments via their selling process. Based on that compendium, and writing in the interdisciplinary journal Business and Politics (Santos and Laczniak, 2012), we generated over four dozen actionable, mid-range decision guidelines for ethically dealing with impoverished consumers and also matched them to the five elements of the IJM (Table 13.4).

\section{Table 13.4 Mid-level decision principles based on the IJM elements}

\begin{tabular}{ll}
\hline IJM Element & Decision Principles \\
\hline $\begin{array}{l}\text { Authentic } \\
\text { engagement }\end{array}$ & $\begin{array}{l}\text { A business firm should strive to develop trust with its } \\
\text { customers at all levels } \\
\text { non-exploitative } \\
\text { intent }\end{array}$ \\
$\begin{array}{l}\text { A business firm ought to develop its competitive advantage } \\
\text { through a process of collaboration rather than focusing on } \\
\text { eliminating competition }\end{array}$ \\
$\begin{array}{l}\text { A business firm ought to take a long-term perspective that } \\
\text { improving the quality of society and the environment is to } \\
\text { the benefit of all } \\
\text { A business firm ought never to take advantage of the relative } \\
\text { weaknesses of its customers. Instead, it should make } \\
\text { maximum efforts, using its own relative strengths to relieve } \\
\text { these shortcomings, so that the consumer experience is } \\
\text { enhanced. In effect, companies ought to build a trustworthy } \\
\text { reputation for fair dealing, dependability, and continuous } \\
\text { care } \\
\text { A business firm ought to encourage employee volunteering } \\
\text { particularly in impoverished neighborhoods } \\
\text { A business firm should foster social sustainability while } \\
\text { ensuring profitability in the long run } \\
\text { A business firm should support the formalization of } \\
\text { consumer rights that guarantee safety, redress, sufficient } \\
\text { information, and other basic requirements of exchange } \\
\text { fairness }\end{array}$ \\
\end{tabular}


IJM Element

Co-creation of value

Investment in

future

consumption
Decision Principles

Instead of autonomously positing what constitutes value for impoverished customers, a firm ought to involve such consumers in the value creation process itself

A business firm ought to use its resources to ensure that its fairly priced offering proposes what is of best economic value for its targeted impoverished customers

A business firm should engage in a co-creation process that fosters sustained partnerships and develops mutual trust with impoverished customers that extends beyond the consumption of the product or service

A business firm ought to leverage local innovativeness and actively seek ways in which its impoverished customers can participate in the value co-creation process

A business firm should constantly seek input from its impoverished customers either directly or through observation and should incorporate this feedback into its decision-making processes

A business firm should consider ways in which its impoverished customers can be given an ownership stake in the company

A business firm ought to partner with local NGOs so as to leverage the expertise, goodwill, and network of the NGO in a mutually advantageous manner

A business firm ought to collaborate with the local communities in which it operates so as to tap into the social network they constitute

A business firm ought to invest in research and development that is aimed at developing innovations for impoverished markets that are both socially beneficial and environmentally friendly

A business firm should strive to increase the capabilities of impoverished segments so as to ensure that these impoverished segments can better participate in the market economy

A business firm ought to pay its employees a living wage so as to ensure that they can contribute to the overall economy of which the firm is also a part

In the conception, production, and delivery of goods or services, a company should strive to ensure that the ecological footprint is minimized

In keeping with an emerging perspective in impoverished markets, a business firm ought to afford access to products and services (for example, leasing or sharing) rather than focusing on ownership of these 
Table 13.4 (continued)

IJM Element Decision Principles

Interest representation of stakeholders
A business firm ought to consider what matters to its stakeholders and is to their advantage. Further, the firm ought to demonstrate through business policies and ethical audits that such accommodations have indeed taken place

A business firm ought to consider its impoverished customers as primary stakeholders as these customers have a continuing and essential interest in the firm and are also vital to the growth and survival of the business initiative once a commitment to target this segment is made

A business firm should encourage its employees to have first-hand experience of the real work of low-income consumers

A business firm should ensure that decision, actions, and procedures that are promulgated do not further disadvantage impoverished customers

A business firm ought to engage in dialogue with impoverished customers regarding its products and services so as to ensure a greater likelihood of the customers' interests being taken into account

A business firm ought to make efforts to understand the difficulties and constraints faced by impoverished customers and try to alleviate them so as to enhance the overall consumer experience. This strategy might involve investing in education, health care, sanitation, and access to credit, which expand the capabilities of the impoverished consumers and enable a richer firm-consumer relationship

A business firm ought to include consumer education and counseling as part of its marketing strategy to ensure better representation of the long-term interests of its impoverished customers and to enable the customers to make better informed choices

A business firm ought to develop and promote products and services that are especially relevant to the impoverished market segment

A business firm ought to enable better access of impoverished customers to the market to enable them to better participate in the market economy

A business firm should make its products and services affordable, accessible, and available 
A business firm should ensure that the information about its products and services are easily understood by its impoverished customers

Long-term profit management
Instead of seeking to maximize financial returns in the short run, a business firm ought to aim at creating sustainable value in the long run

A company, consistent with its role as a social as well as economic institution, ought to consider social goals as ends in themselves rather than as means to a financial end

A business firm ought to increases business success with a long-term perspective based on social, environmental, and financial returns

A business firm ought to view impoverished markets as sources of opportunity, innovation, and competitive advantage

A business firm ought to support local communities in the holistic development in terms of supporting education, health, sports, the arts, and so on, at a scale and focus befitting the local community and culture

Source: Santos and Laczniak (2012).

Second, to those who stated that, while the model had presumptive ethical integrity 'its implementation could never be assured in developing markets because of the abiding competitive market pressures in such settings' (in other words, there are persuasive reasons why so many firms 'race to the bottom'), in response, we introduced the notion of transformational justice in Santos et al. (2015). There we begin to sketch out the importance of endogenous corporate culture - as an institutional force - in assuring that the poor are treated with dignity and fairness. But more centrally, to the greatest extent possible, exogenous forces of various kinds - resident (that is, local government) and external regulatory agencies (for example, the UN) - must exercise their power to insure that consumer rights of the poor are being recognized. Put another way, while the five components of the IJM are aspirational ethical ideals, the institutions of developed economies and the cultures of individual corporations have the levers to transform exchange in order to make market fairness for the poor a more probable scenario. 


\subsection{CURRENT DEVELOPMENT OF THE IJM}

Several types of incremental analyses further elaborating the IJM are taking place:

- Given the real politic of MNCs' profit pressures, many firms will likely not embrace the socially responsible approach advocated by the IJM. Thus, as a separate thrust, Santos (2013) and Facca-Miess and Santos (2014a) began to connect the IJM to social entrepreneurship, where the charter of such firms involve a missiondriven purpose to more directly serve impoverished segments. In these papers, lessons are drawn for the application of the IJM to social entrepreneurship organizations (SEOs) using already published case studies to illustrate potential successes and failures.

- Doctoral students at different universities have expressed an interest in using the IJM as an organizing scheme for their analyses of various 'marketplaces' that deal with the poor and vulnerable. Research included here involves macro-marketing studies of surrogate mother 'rental' in India, wage-challenged consumers in the USA, and aboriginal peoples in Australia/New Zealand attempting to protect the intellectual (and held in common) property rights of their cultures.

- While the IJM is intended as a normative approach for marketing to the poor, that is, it represents the right and proper thing to do regardless of economic cost, some reactors have wondered if utilization of the IJM also might result in greater profits through good ethics. To assist, Facca-Miess and Santos (2014b) have conducted a process of scale construction and validation to calibrate each element of the IJM - inspired by the mid-range decision principles outlined in Santos and Laczniak (2012) - as well as to standardize a methodologically defensible approach for measuring the extent to which the IJM has been embraced in business operations. Initial statistical analysis, using a sample of 118 consumers familiar with organizational outreach to the poor, indicates strong support for the originally stipulated IJM components with two provisos (Facca-Miess and Santos, 2014b). First, factor loadings seem to indicate that 'authentic engagement' and 'investment in future consumption' are really a single variable. This combined variable is re-labeled 'sustainable engagement'. Indeed it seems logical that authentic engagement by sellers cannot typically occur without a palpable investment of time and monies, thereby setting up the foundation for continued operations - that is, engagement $\times$ investment $=$ sustainability. Second, a 
new IJM element emerges, tentatively called 'amplifying the voice of impoverished consumers'; it loads on a set of the items inspired by the above-mentioned Santos and Laczniak (2012) article. To illustrate, the core of the 'amplifying voice' factor consists of (1) making sure input from the impoverished segments is incorporated into decisionmaking; (2) finding ways to give poor customers an ownership stake in the entities with which they regularly do business, and (3) partnering with local organizations to leverage their expertise and goodwill.

\subsection{NEAR FUTURE SUPPLEMENTS TO THE IJM}

While reviewers have been supportive of the notion of institutions playing an important role to assure transformational justice in the marketplace via their stimulus of fair exchange that advances the common good (Santos et al., 2015), several readers questioned how one might define the elusive 'common good'. The specific issue to be addressed is: while institutions inherently have the power to nudge corporations in particular directions, what is the underlying direction of impetus that should guide such policies? To this end, Laczniak and Santos (2015) have begun to elaborate the IJM framework using a 'social capabilities for all' approach (see Sen, 2009) that specifies the means and outcomes that exogenous institutions should strive to advance, deliver, and protect.

For Sen (2009), the inspiration for his approach lies in the purpose of economic activity being to provide all people with the 'functionings' necessary to achieve their life potential. This includes the opportunity to access the essential capabilities to fairly participate in economic life. One can forcefully argue that full access to participation in the economic life of the community will require education, health, and the ability to take advantage of job opportunities. That is, the vision of institutional actions for 'just' exchange should be the creation of an external environment that provides equal opportunity for all consumer-citizens to develop their capabilities. To the extent that institutions (MNCs, SEOs, NGOs, and governments) foster such capabilities, the common good has been advanced and market transactions in the context of the IJM become easier to discharge.

\subsection{CONCLUDING COMMENTS}

We did not create the components of the IJM any more than the founding fathers of America invented the principles of democracy. The duties owed 
to impoverished consumers of every stripe are instead inherent in acclaimed ethical theories of moral philosophy and the best practices of the most enlightened organizations. Further, the IJM should not be portrayed as a tool toward securing greater corporate profit in developing markets - although the embrace of the IJM may or may not lead to higher profits. The goal of the IJM is that it inspires business practitioners to reflect on the conditions of a marketplace that presently includes too many vulnerable buyers who lack bargaining power, whether they be a resident of a Brazilian favela or a recent US immigrant scraping together coach fare for a visit back home to see her elderly mother. The IJM represents some deduced ideals of fair exchange against which current selling practices to poor consumer segments can be measured. Awareness of the IJM is a small and (hopefully) helpful step for academic researchers to utilize in aiding that process or for ethics educators to put forward when discussing economic obstacles facing the poor.

\section{REFERENCES}

American Marketing Association (2008), 'Statement of ethics', accessed 4 June 2015 at https://archive.ama.org/archive/AboutAMA/Pages/Statement\%20of\% 20Ethics.aspx.

Bishop, J.D. (2000), 'A framework for discussing normative theories of business ethics’, Business Ethics Quarterly, 10(3), 563-92.

Dunfee, T.W., C.N. Smith and W.T. Ross, Jr. (1999), 'Social contracts and marketing ethics', Journal of Marketing, 63(3), 14-32.

Enderle, G. (2013), 'The capability approach as guidance for corporate ethics', in C. Luetge (ed.) (2013), Handbook of the Philosophical Foundations of Business Ethics, Berlin: Springer, pp. 675-90.

Facca-Miess, T.M. and N.J.C. Santos (2014a), 'Fostering fair and sustainable marketing for social entrepreneurs in the context of subsistence marketplaces', Journal of Marketing Management, 30(5-6), 501-18.

Facca-Miess, T.M. and N.J.C. Santos (2014b), 'Operationalizing the constructs of the integrative justice model: a useful tool for marketers in varied contexts', paper presented at the 39th Annual Macromarketing Conference, Royal Holloway University, London.

Hamm, S. (2008), 'Capitalism with a human face', BusinessWeek, 8 December, 49-53.

Krämer, A. and F. Belz (2008), 'Consumer integration into innovation processes: a new approach for creating and enhancing innovations for the base of the pyramid?', in P. Kandachar and M. Halme (eds) (2008), Sustainability Challenges and Solutions at the Base of the Pyramid: Business, Technology and The Poor, Sheffield, UK: Greenleaf Publishing, pp. 214-41. 
Laczniak, G.R. (1983), ‘A framework for analyzing marketing ethics’, Journal of Macromarketing, 6(3), 7-18.

Laczniak, G.R. and P.E. Murphy (2006), 'Normative perspectives for ethical and socially responsible marketing', Journal of Macromarketing, 26(2), 154-77.

Laczniak, G.R. and N.J.C. Santos (2011), 'The integrative justice model for marketing to the poor: an extension of the S-D logic to distributive justice', Journal of Macromarketing, 31(2), 135-47.

Laczniak, G.R. and N.J.C. Santos (2015), 'The capabilities approach as a criterion for transformative justice', Working Paper, Marquette University.

Levitt, T. (1983), 'The globalization of markets', The Harvard Business Review (May-June), 92-102.

McMachon, T.F. (1999), ‘Transforming justice: a conceptualization', Business Ethics Quarterly 9(4), 593-602.

McMahon, T.F. (2004), Ethical Leadership through Transforming Justice, Lanham, MD: University Press of America.

Nill, A.L. and J.A. Schibrowsky (2007), 'Research on marketing ethics: a systematic review of the literature', Journal of Macromarketing, 27(3), 25673.

Rangan, V.K. and A. McCaffrey (2004), 'Globalization and the poor', in J. Quelch and R. Deshpande (eds) (2004), The Global Market: Developing a Strategy to Manage Across Borders, San Francisco, CA: Jossey-Bass, pp. 33560.

Reidenbach, R.E. and D.P. Robin (1990), 'Toward the development of a multidimensional scale of improving evaluation of business ethics', Journal of Business Ethics, 9(8), 639-53.

Santos, N.J.C. (2013), 'Social entrepreneurship that truly benefits the poor: an integrative justice approach', Journal of Management for Global Sustainability, 1(2), 31-62.

Santos, N.J.C. and G.R. Laczniak (2006), 'Marketing to the poor: a SWOT analysis of the market construction model for engaging impoverished market segments', paper presented at the conference on Corporate Responsibility and Global Business: Implications for Corporate and Marketing Strategy, London: London Business School.

Santos, N.J.C. and G.R. Laczniak (2009a), “'Just markets” from the perspective of Catholic social teaching', Journal of Business Ethics, 89(1), 29-38.

Santos, N.J.C. and G.R. Laczniak (2009b), 'Marketing to the poor: an integrative justice model for engaging impoverished market segments', Journal of Public Policy \& Marketing, 28(1), 3-15.

Santos, N.J.C. and G.R. Laczniak (2012), 'Marketing to the base of the pyramid: a corporate responsibility approach with case inspired strategies', Business and Politics, 14(1), 1-44.

Santos, N.J.C., G.R. Laczniak and T.M. Facca-Miess (2015), 'The “integrative justice model” as transformative justice for base-of-the-pyramid marketing', Journal of Business Ethics, 126(4), 697-707.

Sen, A. (1999), Development as Freedom, Boston, MA: Belknap of Harvard University Press.

Sen, A. (2009), The Idea of Justice, Cambridge, MA: Belknap of Harvard University Press. 
Smith, C.N. (1995), 'Marketing strategies for the ethics era', Sloan Management Review, 36(4), 85-97.

Sprague, C. (2007), 'Amanz' abantu: water (and sanitation) for the people', Growing Inclusive Markets, United Nations Development Programme, accessed 31 July 2015 at http://www.africa-platform.org/sites/default/files/ resources/south_africa_amanz_abantu.pdf.

Vargo, S.L. and R.F. Lusch (2004), 'Evolving to a new dominant logic for marketing', Journal of Marketing, 68(1), 1-17.

Vargo, S.L. and R.F. Lusch (2006), 'Service-dominant logic: what it is, what it is not, what it might be', in R.F. Lusch and S.L. Vargo (eds), The ServiceDominant Logic of Marketing: Dialog, Debate, and Directions, New York: M.E. Sharpe, pp. 43-56.

Vargo, S.L. and R.F. Lusch (2008), 'Service-dominant logic: continuing the evolution', Journal of the Academy of Marketing Science, 36(1), 1-10.

Williams, O.F. and P.E. Murphy (1990), 'The ethics of virtue: a moral theory for marketing’, Journal of Macromarketing, 10(1), 19-29. 